\title{
As ditaduras civis-militares e os dilemas entre lembrar e esquecer: a representação dual entre Brasil e Argentina
}

\section{The civil-military dictatorships and the dilemma between remembering and forgetting: dual representations between Brazil and Argentina}

\author{
Marcos Oliveira Amorim Tolentino ${ }^{1}$ \\ Pâmela de Almeida Resende ${ }^{2}$
}

\begin{abstract}
Resumo
O objetivo deste artigo é problematizar uma noção comumente aceita de que a Argentina seria o "país da memória", enquanto o Brasil é o "país do esquecimento", devido às políticas públicas desenvolvidas em cada um frente aos legados das recentes ditaduras civis-militares. Para além do senso comum que pontua uma oposição excludente entre memória e esquecimento, há uma tentativa de separação de duas maneiras de agir na política: de um lado, uma que propõe "virar a página" em nome da chamada reconciliação nacional; do outro, a que não pode esquecer sem conhecer, esclarecer e promover o nunca mais. Para tanto, abordaremos as medidas reparatórias adotadas pelos respectivos Estados nos últimos anos nos dois países, de maneira a demonstrar que memória e esquecimento, mais do que uma simples dualidade, conformam os relatos sobre as ditaduras produzidas no Brasil e na Argentina, assim como a relação que hoje tanto Estado quanto a sociedade civil estabelecem com o passado ditatorial.
\end{abstract}

Palavras-chave: memória; Brasil; Argentina.

\begin{abstract}
The purpose of this article is to discuss a notion commonly accepted that Argentina would be the "country of memory" while Brasil is "the country of oblivion". Besides the common sense that scores an exclusive opposition between memory and oblivion, there is an attempt of separation of two courses of political action: one that proposes

\footnotetext{
${ }^{1}$ Mestre em História na área de Política, Memória e Cidade pela Universidade Estadual de Campinas (UNICAMP). Doutorando em História na mesma universidade, onde desenvolve pesquisa intitulada "Porque temos memória, sabemos a verdade, exigimos justiça. A inserção dos sobreviventes dos centros clandestinos de detenção no movimento argentino pelos direitos humanos (1984-2014)", sob orientação do Prof. Dr. José Alves de Freitas Neto. Órgão financiador: CNPq. Endereço para correspondência: Rua Praia de Mar Grande, quadra 15, lote 07. Villas do Atlântico, Bahia. Cep: 42700000. Email: marcosoat@hotmail.com.

${ }^{2}$ Mestra em História Social pela Universidade Estadual de Campinas (UNICAMP). Doutoranda em História pela Universidade de São Paulo (USP), onde desenvolve pesquisa intitulada "Quatro dias em setembro: o sequestro do embaixador Charles Elbrick e as negociações entre Brasil e EUA", sob orientação da Profa. Dra. Elizabeth Cancelli. Endereço para correspondência: Rua Francisco Ianni, 100. Jardim Ubirajara, São Paulo. Cep: 04458090. Email: pamelaresende@ yahoo.com.br.
}

\section{GANPHLAC}

Revista Eletrônica da ANPHLAC, ISSN 1679-1061, Nº. 18, p. 251-286, jan./jul. 2015. http://revista.anphlac.org.br/ 
"turning the page" on behalf of a so-called national reconciliation; and one that can't forget without knowing, clarifying and promoting the "never more". Therefore, we will discuss the reparations taken by Argentinean and Brazilian States in recent years, in order to demonstrate that memory and oblivion, more than a simple duality, are present in the narratives produced in both countries, as well as in the ways that State and civil society deal with the dictatorial past.

Keywords: memory; Brazil; Argentina.

Artigo recebido em: 31 de janeiro de 2015

Artigo aprovado para publicação em: 29 de abril de 2015

Também na Argentina, as Forças Armadas saíram desmoralizadas do poder, seja pelas contumazes violações aos direitos humanos, seja pelo pífio desempenho econômico, seja pela derrota na Guerra das Malvinas. No Brasil, todavia, as Forças Armadas não saíram derrotadas do governo, tanto é que conseguiram, em 1979, negociar com o Congresso uma autoanistia. Pacto este que contribuiu para uma razoável transição pacífica rumo a uma democracia eleitoral [...]. Foram precisos 25 anos para o surgimento de uma proposta concreta para a criação de uma comissão da verdade. Não conheço outro país que tenha demorado tanto a dar esse passo fundamental para a contagem da história verdadeira do país. ${ }^{3}$

Dia desses, mais tarde que cedo, o projeto de lei que instaura a Comissão da Verdade será votado no Senado [...] Restará aos brasileiros o consolo de saber que o que se conseguiu é melhor do que nada. E, ao mesmo tempo, saber que é só um pouco mais do que um imenso nada, diante do que seria justo esperar. Na verdade verdadeira, o Brasil fugiu de um amplo debate sobre o tema da memória e da impunidade. Houve algum debate, por certo, mas de tal forma restrito e manipulado que é como se não tivesse existido [...]. Por esses dias convém lembrar o que aconteceu na Argentina, onde barbárie foi muito mais cruel que no Brasil, e que ainda assim, puniu e pune seus criminosos. Por que eles conseguiram, e nós nem tentamos? [...] Pergunto: qual a grande diferença entre o que se faz na Argentina e o

3 ZAVERUCHA, Jorge. Justiça de transição. Folha de São Paulo, São Paulo, 13. Jan. 2010. http://www1.folha.uol.com.br/fsp/opiniao/fz1301201008.htm?mobile (Verificado em 24/01/2015).

\section{GANPHLAC}

Revista Eletrônica da ANPHLAC, ISSN 1679-1061, №. 18, p. 251-286, jan./jul. 2015. http://revista.anphlac.org.br/ 
que se fez no Brasil? E vejo que não se trata de uma grande diferença: se trata de uma diferença total. ${ }^{4}$

Toda uma geração de trabalhadores, estudantes, sindicalistas e intelectuais foi 'apagada' do mapa pela ditadura argentina. Hoje, 35 anos depois, o país é considerado um modelo na luta contra a impunidade [...]. O êxito da Argentina no campo dos direitos humanos se baseia, segundo o advogado criminalista Wolfgang Kaleck, em dois fatores: 'Em primeiro lugar, o forte movimento pelos direitos humanos que partiu das Mães da Praça de Maio e, em segundo, o uso estratégico que elas fizeram de instâncias políticas e jurídicas, não apenas locais, mas também internacionais, para denunciar crimes e buscar justiça' [...]. Segundo Kaleck, a mobilização das organizações argentinas de direitos humanos no exterior, por exemplo junto à Corte Interamericana de Direitos Humanos, e em tribunais europeus fizeram com que a pressão fosse contínua na Argentina. O trabalho das organizações de direitos humanos e as exigências internacionais são 'exemplares em todos os sentidos', afirma o advogado. ${ }^{5}$

O diretor do Museu dos Direitos Humanos do Mercosul, Márcio Tavares dos Santos, falou sobre o processo de concepção do espaço. "Quando recebemos o aval do bloco para a criação do museu, fizemos uma missão à Argentina para conhecer seu trabalho de resgate da memória, justiça e reparação, que é um exemplo para todos os países da América Latina. Nosso espaço busca atuar como um articulador de ações para superar o legado da violência". ${ }^{6}$

O debate acerca das ditaduras que governaram os países do Cone Sul entre os anos 1960 e o início da década de 1980 tem sido uma constante na mídia e na agenda política dos respectivos governos. Nota-se, por exemplo, uma presença, entre avanços e retrocessos, da demanda por "memória, verdade e justiça", já que em nenhum país a ruptura com o passado violento se deu de maneira completa.

Por outro lado, há uma noção de que, mesmo dentro desse quadro de incompletude democrática, alguns exemplos foram capazes de promover políticas reparatórias com maior eficácia. Nota-se nos debates políticos e acadêmicos atuais uma

\footnotetext{
${ }^{4}$ NEPOMUCENO, Eric. Direitos humanos e a verdade: lições que não quisemos aprender. Carta Capital, 03. Out. 2011. http://cartamaior.com.br/?\%2FEditoria\%2FDireitos-Humanos\%2FDireitos-humanos-e-averdade-licoes-que-nao-quisemos-aprender\%0D\%0A\%2F5\%2F17748 (Verificado em 24/11/2015).

${ }_{5}^{5}$ PAPALEO, Cristina. Argentina é considerada exemplo na luta contra a impunidade. Deutsche Welle, 30. Nov. 2011. http://www.dw.de/argentina-\%C3\%A9-considerada-exemplo-na-luta-contra-a-impunidade/a15564399 (Verificado em 24/01/2015)

${ }^{\frac{1}{6}}$ KIRALY, Letícia. Encontro Internacional sobre impacto da ditadura reúne especialistas na Capital. Portal do Governo do Estado do Rio Grande do Sul, Porto Alegre, 14. Nov. 2014. http://www.rs.gov.br/conteudo/207132/encontro-internacional-sobre-impacto-da-ditadura-reuneespecialistas-na-capital (Verificado em 24/01/2015).
}

\section{GANPHLAC}

Revista Eletrônica da ANPHLAC, ISSN 1679-1061, Nº. 18, p. 251-286, jan./jul. 2015. http://revista.anphlac.org.br/ 
oposição binária clara entre Brasil, como país do esquecimento, e Argentina, como país da memória. Para além do senso comum que pontua uma oposição excludente entre memória e esquecimento, há uma tentativa de separação de duas maneiras de agir na política: aquela que propõe "virar a página" em nome da chamada reconciliação nacional; e aquela que não pode esquecer sem conhecer, esclarecer e promover o "nunca mais". Em um caso, a amnésia; no outro, o chamado "dever de memória". No entanto, em ambos os casos não se trata de uma presença ou de uma ausência completa, nem de memórias sem esquecimentos.

Os trechos citados, retirados de notícias e colunas de opinião pública, veiculados nos últimos cinco anos, tanto no Brasil quanto no exterior, são exemplos da reprodução desses sensos comuns. Em seu texto publicado na seção Tendências / Debates, no jornal Folha de São Paulo, o cientista político Jorge Zaverucha questiona a demora, no caso brasileiro, da instauração de políticas de "justiça de transição", quando comparado com experiências similares de países que viveram sob regimes ditatoriais. Para o autor, a resposta estaria na maneira como a transição democrática foi realizada no Brasil, a partir de uma negociação que teria culminado numa autoanistia, em 1979. Para reforçar tal argumento, há uma comparação com o mais recente exemplo argentino, no qual a derrota na Guerra das Malvinas, em 1982, o fracasso do plano econômico e a magnitude das violações aos direitos humanos cometidas durante sete anos de ditadura fizeram com que as Forças Armadas saíssem do poder desmoralizadas.

A comparação entre Brasil e Argentina também é utilizada no texto do jornalista Eric Nepomuceno para reafirmar uma dicotomia entre a opção pelo esquecimento em detrimento da valorização da memória, respectivamente. Esquecimento este que estaria associado a um desconhecimento e falta de vontade política no sentido de investigar o ocorrido durante a ditadura civil-militar brasileira. Neste quadro, a aprovação da Comissão Nacional da Verdade, em 2011, serviria como um consolo e a reiteração da noção de que no Brasil nada foi feito em relação ao passado ditatorial. Segundo o autor, esta seria a total diferença com a Argentina, onde se conseguiu punir os militares

\section{CANPHLAC}

Revista Eletrônica da ANPHLAC, ISSN 1679-1061, №. 18, p. 251-286, jan./jul. 2015. http://revista.anphlac.org.br/ 
mesmo em se tratando de uma ditadura que teria sido pior que a nossa, recuperando-se indiretamente o "argumento numérico" para hierarquizar experiências de violência.

Os dois últimos trechos afirmam a exemplaridade da Argentina no tratamento com o legado da ditadura. No caso da nota publicada pela agência de notícias alemã Deutsche Welle (DW), o "exemplo argentino" já vem ressaltado em seu título e teria sido o resultado de ações promovidas desde 1983 pelos governos democráticos, apoiadas pela sociedade civil. Para Wolfang Kaleck, advogado criminalista e membro do Centro Europeu de Direitos Humanos e Constitucionais, as organizações de direitos humanos seriam as principais responsáveis devido a seu trabalho "exemplar em todos os sentidos”, garantindo que as pressões fossem contínuas sobre o Estado argentino. Já a última nota recupera a participação de Márcio Tavares dos Santos, diretor do Museu dos Direitos Humanos do Mercosul, na abertura do "Encontro Internacional Diálogos e Formas de Intervenções no Campo da Violência de Estados Ditatoriais", ocorrida em Porto Alegre entre os dias 14 e 15 de novembro de 2014. Em sua fala, ele apontou que foi necessária uma "missão à Argentina", "exemplo para todos os países da América Latina", para elaborar a concepção do espaço do Museu que, por sua vez, se propõe a "apresentar histórias e memórias que corporifiquem as violações aos direitos humanos originadas pela Operação Condor". 8 Nota-se, portanto, uma nítida valorização das iniciativas de reparação argentina em detrimento de espaços reconhecidos em outros países da região, como, por exemplo, o Museo de la Memoria y los Derechos Humanos, em Santiago (Chile).

O objetivo desse artigo é problematizar uma noção comumente aceita de que a Argentina seria o "país da memória", enquanto o Brasil é o "país do esquecimento". Para tanto, abordaremos as medidas reparatórias adotadas pelos respectivos Estados nos últimos anos nos dois países, de maneira a demonstrar que memória e esquecimento, mais do que uma simples dualidade, conformam os relatos sobre as ditaduras

\footnotetext{
${ }^{7}$ De acordo com Caroline Silveira Bauer, há no presente um equívoco interpretativo que considera a ditadura argentina mais violenta que a brasileira, a partir do chamado "argumento numérico". Isso porque, enquanto no Brasil temos aproximadamente 400 casos de mortos e desaparecidos, o regime civil-militar argentino foi responsável, segundo organismos de direitos humanos, por cerca de 30.000 desaparecimentos. No entanto, segundo a autora, os elementos de comparação entre as duas ditaduras devem estar antes nas estratégias repressivas dos respectivos regimes do que no número de vítimas diretas (BAUER, 2012, p. 36).

${ }^{8}$ http://www.mdhm.rs.gov.br/conteudo/971/sobre-o-museu (Verificado em: 25/01/2015).
}

\section{GANPHLAC}

Revista Eletrônica da ANPHLAC, ISSN 1679-1061, Nº. 18, p. 251-286, jan./jul. 2015. http://revista.anphlac.org.br/ 
produzidas em ambas as nações, assim como a relação que hoje tanto Estado quanto a sociedade civil estabelecem com o passado ditatorial.

Pensando no caso brasileiro, buscamos problematizar a ideia de que nada foi feito para romper com a lógica da impunidade decorrente das violações de direitos humanos ocorridas durante a mais recente ditadura civil-militar. Tomando como ponto de partida a conjuntura aberta com as discussões pela aprovação da Lei de Anistia, ainda em 1979, recuperamos a atuação central dos movimentos de luta pela anistia e, posteriormente, o protagonismo dos familiares dos mortos e desaparecidos na luta por memória, verdade e justiça. A partir das demandas desses atores é possível visualizar, então, os avanços, limites e retrocessos das iniciativas governamentais no tratamento do tema, sobretudo a partir dos anos 2000.

Já em relação ao caso argentino, buscamos discutir a suposta superação dos conflitos da memória no país, alcançada a partir das medidas reparatórias adotadas após a eleição de Néstor Kirchner, em 2003. Tais medidas à primeira vista geram a imagem de um consenso entre a sociedade e o Estado argentinos em relação ao passado ditatorial; uma "memória dominante", baseada nas denúncias das violações aos direitos humanos cometidas durante a última ditadura civil-militar. Além disso, reforçam o argumento recorrente nos meios de comunicação brasileiros de que a experiência argentina seria exemplar no Cone Sul, graças, sobretudo, ao processamento judicial de indivíduos envolvidos na repressão. Para problematizar essas duas representações, apontaremos que há limites nas medidas reparatórias argentinas; limites estes que geram conflitos entre os atores sociais vinculados ao passado ditatorial, cada um com sua visão de passado e com suas demandas para o tratamento das marcas coletivas e individuais da violência sistematizada pela ditadura.

\section{As violações de direitos humanos durante a última ditadura civil-militar brasileira: os limites e avanços das medidas reparatórias}

Em 2009 completaram-se 30 anos da promulgação da Lei de Anistia no Brasil. Os eventos e debates em torno do que podemos chamar data convocante estiveram centrados, sobretudo, na lembrança dos mortos e desaparecidos, nas lacunas presentes nas iniciativas governamentais, na existência de arquivos sigilosos e, sobretudo, na

\section{GANPHLAC}

Revista Eletrônica da ANPHLAC, ISSN 1679-1061, Nº. 18, p. 251-286, jan./jul. 2015. http://revista.anphlac.org.br/ 
demanda por memória, verdade e justiça. ${ }^{9}$ As datas comemorativas ${ }^{10}$ têm o poder de ativar a memória, trazem à tona os conflitos existentes entre os diversos atores que querem tornar legítimas suas demandas na cena pública. O dia 28 de agosto de 1979, data em que é sancionada a Lei de Anistia, destaca-se pela sua capacidade de mobilização, pelas lembranças recuperadas e pela noção comumente aceita de uma lei que teria anistiado os torturados, mas também os torturadores. De modo que a atuação dos familiares dos mortos e desaparecidos e de movimentos de direitos humanos que exigem o fim da impunidade está diretamente relacionada às discussões sobre a interpretação dessa lei. ${ }^{11}$ Além disso, é importante ressaltar que, com frequência, o processo de construção da paz pós-conflito é frágil justamente pela manutenção das marcas e legados do regime anterior.

É possível pensar, então, algumas questões e memórias cristalizadas em boa parte da opinião pública e nos meios acadêmicos que ajudaram a obliterar, de alguma maneira, a atuação central da oposição naquele momento, a partir da noção comumente aceita do Brasil como país do esquecimento, reafirmada, sobretudo, pela leitura um tanto enviesada da aprovação da Lei de Anistia, a partir de um grande pacto entre o governo e a oposição civil, e a construção da noção de uma lei que teria beneficiado os dois lados em questão. Além disso, a atuação na cena pública dos familiares dos mortos e desaparecidos, sobretudo a partir da década de 1980, e os limites e avanços das iniciativas governamentais, já na década de 2000, parecem indicar que o tema das violações aos direitos humanos foi e continua sendo objeto de disputa e debates.

Tomando como ponto de partida a conjuntura aberta pelas discussões em torno da aprovação da Lei de Anistia, a segunda metade da década de 1970 seria marcada pela

\footnotetext{
${ }^{9}$ No âmbito dessas comemorações, a Comissão de Anistia lançou o primeiro número da Revista Anistia Política e Justiça de Transição, com o objetivo de constituir um espaço de debate das políticas públicas relacionadas ao tema da ditadura.

10 "Las fechas y aniversarios son coyunturas en las que las memorias son producidas y activadas. Son ocasiones públicas, espacios abiertos, para expresar y actuar los diversos sentidos que se le otorga al pasado, reforzando algunos, ampliando y cambiando otros" (JELIN, 2002b, p. 245).

${ }^{11} \mathrm{Em}$ outubro de 2008, a OAB questionou a validade da interpretação da Lei de Anistia ao protocolar junto ao Supremo Tribunal Federal (STF) uma Ação de Descumprimento de Preceito Fundamental (ADPF). A ADPF n. 153 foi votada no mês de abril de 2010 com o resultado de ação improcedente por sete votos a dois. Disponível http://www.stf.jus.br/arquivo/cms/noticiaNoticiaStf/anexo/ADPF153.pdf. (Verificado em 30/01/2015).
}

\section{GANPHLAC}

Revista Eletrônica da ANPHLAC, ISSN 1679-1061, Nº. 18, p. 251-286, jan./jul. 2015. http://revista.anphlac.org.br/ 
presença central da oposição civil que se organizava e exigia o esclarecimento das circunstâncias das mortes e desaparecimentos; a denúncia das condições dos presos políticos; a punição dos envolvidos em crimes de lesa-humanidade; anistia ampla, geral e irrestrita; o retorno ao Estado de direito; e a libertação de brasileiros $\operatorname{presos}^{12} \mathrm{em}$ outros países sob regimes ditatoriais na América Latina.

Aos poucos, o termo anistia, principal bandeira agregadora dos movimentos sociais da época, tornou-se uma palavra de ordem central entre as demandas da oposição, a partir da constituição de movimentos pela anistia. Nessa conjuntura e, principalmente, a partir de 1978, com a criação dos Comitês Brasileiros pela Anistia (CBAs), houve um fortalecimento da demanda pela anistia, já que a cena pública passou a ser ocupada por manifestações e "Dias Nacionais de Protesto e Luta pela Anistia". Como destaca Heloísa Greco, uma das “dimensões fundacionais" desse movimento está expressa em sua bandeira de luta e no seu conteúdo programático. Neles é possível perceber explicitamente a produção de uma contramemória e de um contradiscurso presentes na defesa do resgate da memória do terror (GRECO, 2003, p. 357). Assim, o intuito é promover o espaço de escuta e da fala entre os sobreviventes e os familiares de desaparecidos e criar redes de denúncia, solidariedade e ocupação dos espaços públicos.

Desse modo, os movimentos pela anistia - principalmente após a criação dos CBAs - pressionavam cada vez mais o governo para se pronunciar diante do tema. Se durante o mandato do presidente Ernesto Geisel (1974-1978) a questão da anistia não apareceu de maneira central nos debates parlamentares, quando o general João Figueiredo assumiu, em março de 1979, o governo já acenava com a possibilidade de elaboração de um projeto de lei, ainda que não em conformidade com o que queriam os movimentos: uma anistia que fosse ampla, geral e irrestrita. Ao longo desse ano, o regime percebeu que era necessária a mudança de discurso, além de ser obrigado a reconhecer a existência de um movimento cada vez mais articulado, com diferentes atores e múltiplas

\footnotetext{
${ }^{12}$ Como parte da luta pela anistia, os CBAs promoveram constantes campanhas de denúncia com o intuito de desgastar a imagem da ditadura e popularizar a luta no exterior. A campanha pela libertação dos "Flávios" (Flávio Tavares, Flávio Koutzii e Flávia Schilling) está inserida nesse contexto, já que a prisão dos três ocorreu na mesma época, nos países em que se encontravam exilados no Cone Sul. A imagem da juventude perdida foi bastante utilizada pelos movimentos que lutavam pelo retorno deles ao Brasil. Ver (TRINDADE, 2009).
}

\section{GANPHLAC}

Revista Eletrônica da ANPHLAC, ISSN 1679-1061, №. 18, p. 251-286, jan./jul. 2015. http://revista.anphlac.org.br/ 
demandas, como o custo de vida, as reivindicações estudantis, o movimento dos trabalhadores e a própria bandeira da anistia. Nessa conjuntura, o ano de 1979 pode ser encarado como decisivo para a luta pela anistia, não apenas pela intensificação das mobilizações nas ruas e também no Congresso, mas porque ficava cada vez mais claro o embate anistia ampla, geral e irrestrita versus anistia parcial.

Para o regime, tornava-se necessário conduzir o processo de abertura política e as discussões em torno da aprovação da Lei de Anistia dentro dos "limites da ordem", de modo a cristalizar na opinião pública e nos meios parlamentares a ideia de que uma anistia ampla, geral e irrestrita não passava de uma bandeira de setores "revanchistas" ou de "maus cidadãos" que não queriam promover a conciliação da sociedade brasileira. Mesmo não fazendo menção em seu discurso de posse à questão da anistia, ${ }^{13}$ esse assunto estava na "pauta do dia" para o novo governo. No dia 27 de junho de 1979, o presidente Figueiredo enviou ao Congresso Nacional uma mensagem, na qual afirmava:

A anistia é um ato unilateral de Poder, mas pressupõe, para cumprir sua destinação política, haja, na divergência que não se desfaz, antes se reafirma pela liberdade, o desarmamento dos espíritos pela convicção da indispensabilidade da coexistência democrática. A Anistia reabre o campo de ação política, enseja o reencontro, reúne e congrega para a construção do futuro e vem na hora certa (ACE 2247/79. Fundo Serviço Nacional de Informações. Arquivo Nacional).

Esse comunicado seria acompanhado do projeto de lei de anistia, enviado pelo governo, que passaria a ser discutido pela Comissão Parlamentar Mista, nomeada pelo presidente do Congresso, o senador Teotônio Vila (MDB). A análise dos trabalhos da Comissão Mista $^{14}$ é fundamental na tentativa de compreender os debates e a posterior redação do texto final da Lei de Anistia. Assim, no dia 22 de agosto de 1979, em um congresso que contava também com a presença de senadores biônicos, foi votada - e

\footnotetext{
${ }^{13}$ Em seu discurso de posse, em 15 de março de 1979, o general João Figueiredo comprometeu-se a dar prosseguimento ao processo de abertura política, mas também aos ideais que nortearam a "Revolução de 1964". Nas palavras dele: "Reafirmo, portanto, os compromissos da Revolução de 1964, de assegurar uma sociedade livre e democrática. Por todas as formas a seu alcance, assim fizeram, nas circunstâncias de seu tempo, os presidentes Castelo Branco, Costa e Silva, Emílio Médici e Ernesto Geisel. Reafirmo: é meu propósito inabalável - dentro daqueles princípios - fazer deste país uma democracia”. Disponível em: http://www.biblioteca.presidencia.gov.br/ex-presidentes/jb-figueiredo/discursos-de-posse/discursode-posse/view. (Verificado em 24/01/2015).

${ }^{14}$ Congresso Nacional. Comissão Mista sobre Anistia. Anistia.
}

\section{CANPHLAC}

Revista Eletrônica da ANPHLAC, ISSN 1679-1061, Nº. 18, p. 251-286, jan./jul. 2015. http://revista.anphlac.org.br/ 
derrotada por 209 votos contra 194 - a proposta de anistia da oposição, elaborada pelo MDB. No mesmo dia, a emenda Djalma Marinho (Arena) que garantiria, caso aprovada, maior abrangência para o projeto de lei, também não conseguiu passar no Congresso, tendo sido derrotada por uma pequena margem de votos: 206 contra 201.

Durante todo o processo de votação, ${ }^{15}$ ressaltando-se os debates acalorados, os parlamentares da Arena tentaram argumentar que uma anistia ampla, geral e irrestrita poderia trazer à tona os espíritos revanchistas, que em nada dialogavam com o sentimento de conciliação presente no projeto de lei. De modo que, em 28 de agosto de 1979, foi sancionada a lei n. 6.683 nos moldes do Executivo, que estabelecia:

Art. $1^{\circ}$ É concedida anistia a todos quantos, no período compreendido entre 2 de setembro de 1961 e 15 de agosto de 1979, cometeram crimes políticos ou conexos com estes, crimes eleitorais, aos que tiveram seus direitos políticos suspensos e aos servidores da administração direta e indireta, de fundações vinculadas ao poder público, aos servidores dos poderes legislativo e judiciário, aos militares e aos dirigentes e representantes sindicais, punidos com fundamentos em Atos Institucionais e Complementares.

$\S 1^{\circ}$ Consideram-se conexos, para efeitos deste artigo, os crimes de qualquer natureza relacionados com crimes políticos ou praticados por motivação política.

$\S 2^{\circ}$ Excetuam-se dos benefícios da anistia os que foram condenados pela prática de crimes de terrorismo, assalto, sequestro e atentado pessoal. ${ }^{16}$

O parágrafo $1^{\circ}$ da lei, ao determinar a anistia aos chamados "crimes conexos", acabou por estabelecer uma relação de conexidade inexistente entre os crimes cometidos por civis e aqueles cometidos pelo Estado. Consagrou-se, então, a interpretação de que a anistia teria sido recíproca ao anistiar tanto os torturadores quanto as vítimas do regime. Porém, segundo Lucia Elena Bastos, "não se poderia encontrar equivalência de causas ou motivações entre o ato do que afronta o sistema político em vigor (crime político) e o do que reprime (crime de tortura e de desaparecimento forçado), uma vez que o primeiro anseia por mudanças, ao passo que o segundo quer

\footnotetext{
${ }^{15}$ Para maiores detalhes sobre o embate parlamentar, ver: FICO, 2011; TELES, 2010.

${ }^{16}$ Disponível em: http://www.planalto.gov.br/ccivIl_03/Leis/L6683.htm. (Verificado em 24/01/2015).
}

\section{GANPHLAC}

Revista Eletrônica da ANPHLAC, ISSN 1679-1061, Nº. 18, p. 251-286, jan./jul. 2015. http://revista.anphlac.org.br/ 
manter o status quo e age, portanto, de acordo com os interesses que ele pretende preservar" (BASTOS, 2009, p. 393).

Desse modo, a aprovação da lei $6.683 / 79$ não significou o encerramento das discussões em torno do tema. Em primeiro lugar, pelo fato de não abranger todos os presos políticos como, por exemplo, aqueles envolvidos nos chamados "crimes de sangue" que, ao contrário do que se costuma supor, só foram libertados em razão de reformulações na Lei de Segurança Nacional, em 1978. Além disso, os movimentos que lutavam pela anistia ampla, geral e irrestrita não ficaram plenamente satisfeitos com a maneira como o projeto foi aprovado. A localização do corpo de Eurico Tejera Lisbôa ${ }^{17}$ em agosto de 1979, por exemplo, ocorreu de maneira simultânea à aprovação da lei 6.683, demonstrando-se de maneira clara a limitação da proposta do governo e a violência ditatorial (RODEGHERO, DIENSTMANN, TRINDADE, 2011, p. 258).

Em relação à pressão dos familiares pela localização dos desaparecidos políticos, a lei garantiu apenas um "atestado de morte presumida", com a alegação de que mais do que isso poderia significar um rompimento no processo de transição em curso (TELES, 2007, p. 83). Além disso, de acordo com os movimentos de luta pela anistia, o aparato repressivo e as estruturas autoritárias do regime, principalmente contra os movimentos populares, mantinham-se ativas. ${ }^{18}$ No entanto, algumas conquistas - como o retorno dos exilados, a libertação de boa parte dos presos políticos, tendo em vista a revisão das penas, e o surgimento de novos partidos - acabaram por conferir um esvaziamento progressivo dos Comitês Brasileiros pela Anistia.

A partir daquele momento e aos poucos, novos atores se destacaram na luta em favor da localização dos desaparecidos e da responsabilização dos culpados pelos crimes da ditadura. Na década de 1980 surgem pelo menos duas entidades que irão contribuir de maneira significativa para o prosseguimento da luta por memória, verdade e justiça. O Grupo Tortura Nunca Mais foi criado em 1985, no Rio de Janeiro, por

\footnotetext{
${ }^{17}$ Eurico Tejera Lisbôa foi preso em São Paulo, em 1972, em circunstâncias desconhecidas. Mesmo após a localização do seu corpo, o nome de Eurico foi mantido na lista de desaparecidos políticos como uma maneira de insistir na denúncia e na investigação sobre as circunstâncias de sua morte (COMISSÃO DE FAMILIARES DE MORTOS E DESAPARECIDOS POLÍTICOS; IEVE, 2009, pp. 367-371).

${ }^{18}$ Para uma análise do controle e vigilância da comunidade de informações e segurança aos movimentos pela anistia, ver: RESENDE, 2015.
}

\section{GANPHLAC}

Revista Eletrônica da ANPHLAC, ISSN 1679-1061, Nº. 18, p. 251-286, jan./jul. 2015. http://revista.anphlac.org.br/ 
familiares e ex-presos políticos. Sua luta está vinculada à busca dos desaparecidos e ao esclarecimento de suas mortes, além da defesa dos direitos humanos. A Comissão de Familiares de Mortos e Desaparecidos Políticos também tem como principais bandeiras a luta pelo reconhecimento das mortes e desaparecimentos e a condenação da suposta reciprocidade contida na Lei de Anistia.

Desse modo, a compreensão das ações empreendidas pelo Estado brasileiro na década de 1990, mas sobretudo a partir dos anos 2000, precisa ser problematizada também pela presença dos sobreviventes e dos familiares de desaparecidos na cena pública. No ano de 1995, por exemplo, já no mandato do presidente Fernando Henrique Cardoso, a Comissão de Familiares apresentou ao governo algumas lacunas na Lei de Anistia de 1979 e cobrou um posicionamento quanto à responsabilidade perante os crimes e sua consequente reparação. Após muitas discussões, em dezembro do mesmo ano o governo aprovou em caráter de urgência urgentíssima (GONÇALVES, 2009, p. 61) a lei 9.140/1995, também conhecida como Lei dos Desaparecidos Políticos. Esse ato possibilitou importantes e significativas mudanças: o reconhecimento da responsabilidade, por parte do Estado, pelas mortes, torturas, desaparecimentos ${ }^{19} \mathrm{e}$ sequestros; a indenização aos familiares dos mortos e desaparecidos; e a criação da Comissão Especial sobre Mortos e Desaparecidos Políticos (CEMDP). ${ }^{20}$ No entanto, para os familiares, assim como a Lei de Anistia, a lei 9.140 teria sido aprovada com uma série de limitações que impossibilitavam, entre outras ações, a apuração das circunstâncias dos crimes cometidos e a identificação dos responsáveis.

Não se pode dizer que os familiares aprovaram o texto do projeto de maneira integral. Ainda que reconhecessem a importância da iniciativa, eles reclamaram da falta de critérios objetivos para se distinguir mortos e desaparecidos, do ônus da prova ter sido deixado aos próprios familiares, além da impossibilidade de se examinar as circunstâncias das mortes. Também não aceitaram a argumentação do governo, de que essa impossibilidade se devia aos limites impostos pela Lei de Anistia (MEZAROBBA, 2006, p. 90).

\footnotetext{
${ }^{19}$ A listagem das pessoas consta no Anexo I da lei.

${ }^{20}$ Vinculada ao Ministério da Justiça, essa comissão foi formada por um membro das Forças Armadas, um do Itamaraty, um do Ministério Público e um da Comissão de Familiares, representada por Suzana Keniger Lisbôa.
}

\section{CANPHLAC}

Revista Eletrônica da ANPHLAC, ISSN 1679-1061, Nº. 18, p. 251-286, jan./jul. 2015. http://revista.anphlac.org.br/ 
Ainda no âmbito governamental, em 2001 foi criada a Comissão de Anistia, vinculada ao Ministério da Justiça. À Comissão cabe receber os requerimentos de anistia e de indenização ${ }^{21}$ para aqueles perseguidos por motivação política entre 1946 e 1988, analisar os casos e proceder ao deferimento ou indeferimento, assim como estabelecer a indenização a ser recebida. Desse modo, são dois os grandes grupos de perseguidos políticos reconhecidos pela lei n. $10.559^{22}$ : o cidadão violado em suas liberdades públicas e sua integridade física e aqueles que foram demitidos dos seus empregos durante o regime ditatorial. Além da dimensão econômica, tem-se o ato simbólico no qual o Estado pede desculpas oficiais pelas violações cometidas.

Assim, pode-se visualizar uma dupla perspectiva nas ações empreendidas pela Comissão de Anistia: uma, institucional, e outra, pública. No caso da primeira tem-se, além dos pedidos de requerimento de anistia, a formação de um acervo ${ }^{23}$ que, gerado a partir da constituição de "legados pessoais", traz à tona não apenas as perseguições sofridas, mas também a construção de uma narrativa histórica do ponto de vista dos atingidos e a dimensão da reparação que se traduz em reconhecimento social e público da militância exercida contra a ditadura e os efeitos que o regime ditatorial produziu em suas vidas. No interior dos processos é possível encontrar, por exemplo, documentos pessoais, livros, boletins publicados por movimentos de direitos humanos, documentos produzidos por agentes do regime e arquivados no Arquivo Nacional e nos DOPS (Delegacia de Ordem Política e Social) estaduais, além de depoimentos dos perseguidos políticos. Essa multiplicidade de documentos deve vir acompanhada do necessário rigor na pesquisa histórica evitando, assim, a exploração da dor alheia e a vitimização ou

\footnotetext{
${ }^{21}$ A Comissão de Anistia foi criada no ano de 2001, pela Medida Provisória n. ${ }^{\circ}$ 2.151; posteriormente foi convertida na Lei $\mathrm{n}^{\circ} 10.559$ de 13 de novembro de 2002. No site da Comissão de Anistia, há uma relação das normas e procedimentos para aqueles que pretendem requerer anistia. De modo que, à solicitação, devem ser anexados os documentos que comprovem a alegação do requerente, como a perda de emprego por motivação política. Disponível em: http://portal.mj.gov.br/data/Pages/MJABFF735EITEMIDF6425A864D1448ACB9FC7B3A1CDC1022PT BRNN.htm (Verificado em 24/01/2015).

${ }^{22}$ Aprovada em 2002, essa lei deu uma abrangência maior à Lei de Anistia, já que além da Declaração de Anistiado Político, estabeleceu o direito à reparação econômica, à conclusão de cursos interrompidos e a reintegração de servidores públicos.

${ }^{23}$ Os processos gerados a partir da solicitação do pedido de anistia e o conjunto de documentos apresentado ficam arquivados no Setor de Arquivo e Memória da Comissão de Anistia. Esse acervo tem uma importante função histórica ao resguardar informações relevantes acerca das perseguições praticadas pelo regime civil-militar, mas também pelas histórias pessoais que são trazidas à tona.
}

\section{GANPHLAC}

Revista Eletrônica da ANPHLAC, ISSN 1679-1061, Nº. 18, p. 251-286, jan./jul. 2015. http://revista.anphlac.org.br/ 
heroicização daquele que narra. Na busca por "memória, verdade e justiça", há um mapeamento do perfil dos requerentes, dos processos que são contemplados com posterior indenização, além da própria publicização de uma versão até então subterrânea e marginalizada dos acontecimentos.

No caso da dimensão pública, ganha destaque a realização das Caravanas da Anistia, uma das ações do projeto "Anistia política: educação para a cidadania e os direitos humanos", no qual o Estado formaliza um pedido oficial de perdão àqueles atingidos pelo regime. Por ocasião da $24^{\mathrm{a}}$ Caravana de Anistia, em que o Estado brasileiro fez um pedido de desculpas coletivo a 44 camponeses perseguidos durante a Guerrilha do Araguaia, Paulo Abrão, presidente da Comissão de Anistia, afirmou:

[...] eles são protagonistas da construção da democracia no país. Por isso, devemos dar um pouco de justiça e reconhecimento, para que a nossa sociedade tenha conhecimento das consequências de um regime ditatorial, que não atingiu somente os que estão nos grandes centros e famosos líderes. Temos uma tarefa constitucional e oficial a cumprir com essas pessoas (ABRÃO, 2009).

Em eventos como a Caravana, familiares, amigos e ex-perseguidos políticos são convidados a compartilhar esse momento marcado por um forte apelo emocional ao promover o espaço da escuta e da fala, além do resgate de histórias e memórias dos personagens em questão. A historiadora Maria Paula Araújo, no âmbito do projeto "Marcas da memória", realizou uma série de entrevistas com perseguidos políticos, familiares de mortos e desaparecidos, participantes da luta pela anistia e pessoas que foram anistiadas ou estão solicitando o benefício. Entre os entrevistados que foram anistiados, há uma unanimidade no sentido de reconhecerem a importância da dimensão simbólica do pedido de perdão por parte do Estado nas caravanas de anistia, uma vez que "para todos eles o pedido de perdão do Estado é o elemento chave da reparação" (ARAÚJO, 2012, p. 29). Além disso, a importância dessas caravanas está contida, principalmente, no seu caráter público e de ocupação de diferentes espaços, como universidades, escolas, sindicatos, já que:

A dimensão pública das Caravanas ganha relevo especialmente para a juventude, que não vivenciou os anos de repressão. A mensagem levada para os jovens e estudantes é a de que a democracia nunca é

\section{GANPHLAC}

Revista Eletrônica da ANPHLAC, ISSN 1679-1061, № . 18, p. 251-286, jan./jul. 2015. http://revista.anphlac.org.br/ 
um processo acabado, mas sim um processo aberto e, portanto, permanentemente sujeito a avanços e retrocessos. Essa percepção permite inserir o jovem como protagonista na história nacional, como agente da construção do processo democrático. Verificando os danos que a arbitrariedade causou à cidadania, reforça-se uma cultura democrática e republicana de respeito às leis e participação política na tomada de decisões (MINISTÉRIO DA JUSTIÇA, 2009, p. 18).

A centralidade desses atos também está contida nos encontros geracionais que proporciona ao contribuir para que a valorização da defesa dos direitos humanos não esteja restrita apenas aos diretamente atingidos pelo regime ou seus familiares. Nesse conjunto de iniciativas está inserido também o lançamento, em 2007, do livro-relatório Direito à memória e à verdade, ${ }^{24}$ que contém o registro dos trabalhos da Comissão Especial de Mortos e Desaparecidos Políticos (CEMDP) e a relação dos mortos e desaparecidos reconhecidos oficialmente pelo Estado.

No decorrer do ano de 2009, algumas medidas contribuíram para a visibilidade das violações ocorridas durante o período ditatorial e o debate das políticas públicas relacionadas ao tema. No mês de maio foi criado, no âmbito da Casa Civil da Presidência da República, o Centro de Referência das Lutas Políticas no Brasil (19641985) - Memórias Reveladas, ${ }^{25}$ que reúne informações sobre o acervo arquivístico relacionado ao tema da repressão política e custodiado por diferentes instituições brasileiras. A partir da disponibilização de uma base de dados no site, é possível ter conhecimento dos arquivos abertos à consulta pública, além de informações sobre sua localização e política de acesso. Ainda no ano de seu lançamento, o Memórias Reveladas elaborou uma propaganda para a televisão cujo objetivo era chamar atenção da população para informações que pudessem levar à localização dos mortos e desaparecidos políticos. Mesmo que não fossem contrários à campanha de arrecadação de documentos, os familiares criticaram o tom da propaganda, já que, de acordo com Caroline Bauer:

\footnotetext{
${ }^{24}$ Esse livro foi publicado pela Secretaria Especial de Direitos Humanos da Presidência da República e lançado, em 2007, durante o segundo mandato do presidente Lula. Disponível em: http://portal.sdh.gov.br/.arquivos/livrodireitomemoriaeverdadeid.pdf. (Verificado em 24/01/2015).

25 http://www.memoriasreveladas.arquivonacional.gov.br/cgi/cgilua.exe/sys/start.htm?tpl=home. (Verificado em 24/01/2015).
}

\section{CANPHLAC}

Revista Eletrônica da ANPHLAC, ISSN 1679-1061, No. 18, p. 251-286, jan./jul. 2015. http://revista.anphlac.org.br/ 
Analisando-se essas propagandas, percebe-se que o governo federal ainda produz um dos principais argumentos utilizados pelos militares para negar a existência dos desaparecidos: o fato de que eles estão vivos, vivendo com outras identidades, apartados de suas famílias. Daí decorre o paradoxal do Estado brasileiro para que seus cidadãos forneçam informações que possibilitem encontrar os desaparecidos políticos, quando na verdade, os governos têm obrigações internacionais e prerrogativas para disponibilizarem os arquivos das Forças Armadas e demais órgãos de informação e repressão da ditadura civil-militar. (BAUER, 2012, p. 263)

A recente aprovação da Comissão Nacional da Verdade (Lei n. 12528), em 2011, também está inserida nessa perspectiva de promover uma integração entre memória, verdade e reparação, por meio do esclarecimento dos casos de violações de direitos humanos, reconhecendo-os como crimes de lesa-humanidade. A publicação do relatório final de atividades, em dezembro de 2014, trouxe à tona o trabalho realizado durante esses anos, como a requisição de documentos públicos e a convocação de testemunhas. Além disso, reconhece os crimes cometidos pelo Estado e aponta "as recomendações do colegiado para que não se repitam as graves violações de direitos humanos em nosso país". ${ }^{26}$ De acordo com Alexandra Barahona de Brito, o termo "Comissão da Verdade" tem sua origem na América Latina, com a instalação de comissões criadas no âmbito governamental (Argentina, Chile e, mais recentemente, o Brasil), mas também relatórios da verdade, fruto de iniciativas de organizações não-governamentais (casos de Brasil, Peru, Paraguai, Uruguai e Bolívia) (BRITO, 2009, p. 61). A despeito das especificidades de cada caso, há uma preocupação que é comum a todas essas iniciativas: a proteção aos direitos humanos como valor universal.

Nesse sentido, pensando no caso brasileiro, a criação da Comissão Nacional da Verdade, a aprovação da Lei de Acesso à Informação, a disponibilização de alguns acervos referentes ao período ditatorial, o projeto Marcas da Memória, a criação do Memorial da Anistia e outros espaços de memorialização, a implantação das Clínicas do Testemunho, entre outras iniciativas, fazem parte da necessária complementariedade entre reparação, verdade, memória e justiça. Essas iniciativas contribuem de maneira decisiva para a construção de um Estado democrático mais justo, pautado na

\footnotetext{
${ }^{26}$ Disponível em: http://www.cnv.gov.br/index.php/outros-destaques/574-conheca-e-acesse-o-relatoriofinal-da-cnv (Verificado em 30/01/2015).
}

\section{GANPHLAC}

Revista Eletrônica da ANPHLAC, ISSN 1679-1061, Nº. 18, p. 251-286, jan./jul. 2015. http://revista.anphlac.org.br/ 
prerrogativa do "lembrar para não repetir jamais". Ademais, a urgente e necessária adoção de medidas para tratar o legado autoritário é fundamental não apenas para o aprofundamento das discussões acadêmicas sobre os mecanismos necessários para o estabelecimento da paz pós-conflito, mas, sobretudo, para o aprimoramento das políticas públicas já instituídas e o compartilhamento de outras experiências em curso. Torna-se necessário, então, refletir sobre a importância das comissões de verdade; a atuação central dos tribunais de justiça; o papel de destaque da Comissão Interamericana de Direitos Humanos (CIDH); o programa de reparação estabelecido pela Comissão de Anistia; as iniciativas da sociedade civil; o reconhecimento físico das violações de direitos humanos, mediante espaços de memória, museus, placas comemorativas, etc.

Nesse sentido, apesar de todas as dificuldades enfrentadas, é possível visualizar avanços significativos no tratamento do tema. De acordo com Paulo Abrão e Marcelo Torelly, não é possível desconsiderar dois fatores na tentativa de entender as políticas reparatórias promovidas pelo Estado: i) a questão da anistia percebida como uma reivindicação popular, e não como um pacto entre o regime e a oposição civil; ii) a legitimidade das medidas de reparação a partir do seu caráter estruturante, e não fruto de uma alienação social (ABRÃO; TORELLY, 2011, pp. 473-5). Para esses autores, há uma conexão entre a anistia de 1979 e o incremento da demanda transicional na segunda metade dos anos 2000. De modo que, se etimologicamente a palavra anistia significa esquecimento e amnésia social, os trabalhos das comissões de reparações nos últimos anos têm trazido à tona um processo de ressignificação desse sentido, entendido agora como verdade/justiça e reparação individual e/ou coletiva. A ideia é que a observação das medidas reparatórias efetivadas seja entendida não como um modelo pronto a ser seguido, mas como guias cujo aprendizado é constante. De acordo com Vera Vital Brasil:

[...] fazer memória, fazer justiça aos afetados é reparar o dano causado. Porém, há danos irreparáveis. Não há como recobrar a vida dos assassinados, nem recuperar o tempo em que se viveu sob a ameaça de morte. Mas há a possibilidade de se fazer frente ao dano político, reconhecendo os crimes, a injustiça, dando escuta aos injustiçados, quebrando o silêncio das testemunhas, criando políticas que garantam os direitos de cidadania. Políticas que, ao permitir

\section{GANPHLAC}

Revista Eletrônica da ANPHLAC, ISSN 1679-1061, №. 18, p. 251-286, jan./jul. 2015. http://revista.anphlac.org.br/ 
visibilidade, dar existência e reconhecimento aos atingidos, promovem um salto a mais em direção à democracia (BRASIL, 2012, p. 254).

Percebe-se, então, que obstáculos de todo tipo são visíveis cotidianamente, seja nas iniciativas governamentais e seus limites e retrocessos; ou, então, os questionamentos sobre as continuidades e rupturas estabelecidas entre os regimes ditatoriais e as democracias recém-estabelecidas. Nessa conjuntura, a ausência de responsabilização judicial para os envolvidos nos crimes de lesa-humanidade certamente constitui um entrave para a conformação de um Estado de Direito mais justo. A ausência-presença (BAUER, 2012, p. 29) dos desaparecidos políticos em nossa democracia representa, sem dúvidas, resquícios do horror vivido naqueles anos. Por outro lado, acreditamos que o debate acerca das violações de direitos humanos ocorridas durante a mais recente ditadura civil-militar brasileira não pode ficar restrito apenas ao âmbito do discurso que reitera, com alguma insistência, a noção de que nada foi feito para reconhecer a culpa estatal. Se é preciso lutar para o aprofundamento de políticas públicas e pedagógicas visando à não repetição dos crimes e ao conhecimento social das arbitrariedades cometidas, torna-se fundamental reconhecer os avanços conquistados e a presença marcante dos sobreviventes e dos familiares dos mortos e desaparecidos enquanto sujeitos centrais para o pleno estabelecimento do nunca mais.

\section{As medidas reparatórias na Argentina e a suposta superação dos conflitos pela memória da última ditadura civil-militar}

No dia 13 de dezembro de 2014, realizou-se na Plaza de Mayo um ato em comemoração aos 31 anos de democracia. Da Casa Rosada, a atual presidente, Cristina Kirchner, fez um discurso no qual, segundo suas palavras "partindo de uma perspectiva histórica", realizou um balanço do projeto de governo iniciado em 2003 com a eleição de seu falecido marido, o ex-presidente Néstor Kirchner. Acompanhada de governadores, legisladores, "netos recuperados", madres e abuelas de Plaza de Mayo,

\section{GANPHLAC}

Revista Eletrônica da ANPHLAC, ISSN 1679-1061, №. 18, p. 251-286, jan./jul. 2015. http://revista.anphlac.org.br/ 
Cristina afirmou que o projeto kirchnerista, dentre outras coisas, seria o projeto "da Memória, da Verdade e da Justiça”. ${ }^{27}$

O discurso da presidenta foi precedido por uma apresentação musical, na qual o músico Ignacio Guido Montoya Carlotto tocou no piano uma versão da música "Los dinosaurios". Acompanhado pelo cantor Palo Pandolfo, eles estavam encarregados de abrir um bloco musical na Plaza de Mayo de 31 canções do rock argentino "em homenagem à democracia e aos direitos humanos", que terminou cancelado devido à chuva. $^{28}$ Desde que teve sua identidade restituída, comprovando-se que era o neto apropriado da presidenta da Asociación Civil Abuelas de Plaza de Mayo, Estela de Carlotto, seria a primeira vez que o músico tocaria na Plaza de Mayo, num evento oficial. $^{29}$ A escolha da música não foi menos significativa: lançada em 1983 pelo roqueiro Charly García, "Los dinosaurios" descreve metaforicamente a última ditadura civil-militar (1976-1983) e o desaparecimento forçado de pessoas e é considerado um dos hinos da redemocratização.

O evento oficial foi marcado também pela entrega do prêmio Azucena Villaflor. Instituído em 2003, o prêmio homenageia uma das primeiras madres de Plaza de Mayo,

\footnotetext{
${ }^{27}$ LANTOS, Nicolás. "Que nos explique cuál es el proyecto". Página/12, 14 Dez. 2014. Disponível em: http://www.pagina12.com.ar/diario/elpais/1-261948-2014-12-14.html (Verificado em 25/01/2015); PRESIDENCIA DE LA NACIÓN ARGENTINA. "Acto por el $31^{\circ}$ aniversario de la Democracia y Día Internacional de los Derechos Humanos: Palabras de la Presidenta de la Nación". Disponível em: http://www.presidencia.gob.ar/discursos/28270-acto-por-el-31o-aniversario-de-la-democracia-y-diainternacional-de-s-derechos-humanos-palabras-de-la-presidenta-de-la-nacion $\quad$ (Verificado em 25/01/2015).

${ }^{28}$ YACCAR, María Daniela. Al piano, en la Casa Rosada. Página/12, 14 Dez. 2014. Disponível em: http://www.pagina12.com.ar/diario/elpais/1-261946-2014-12-14.html (Verificado em 25/01/2015).

${ }^{29}$ Laura de Carlotto militava na organização Montoneros quando foi sequestrada, grávida de dois meses e meio, em Buenos Aires, em 26 de setembro de 1977. Em 26 de junho de 1978, num hospital militar, Laura deu à luz um menino, a quem deu o nome de seu pai, Guido. Sua mãe, Estela de Carlotto, é atualmente a presidenta da Asociación Abuelas de Plaza de Mayo. Em abril de 1978, uma companheira de cativeiro de sua filha contou-lhe que Laura estava no centro clandestino La Cancha, que funcionava na cidade de La Plata, e que se encontrava grávida. Estela começou então a participar das atividades realizadas por mulheres que buscavam por seus filhos e netos desaparecidos. Em 25 de agosto de 1978, os militares lhe entregaram o cadáver de sua filha, mas ocultaram informações sobre a gravidez e sobre o nascimento do seu neto. Em junho de 2014, após se inteirar de que era adotado, Ignacio Montoya buscou voluntariamente as Abuelas de Plaza de Mayo para descobrir se era filho de algum desaparecido. Dois meses depois, em 05 de agosto de 2014, Abuelas divulgaram publicamente que os exames de DNA apontavam que Ignacio era, na verdade, Guido Carlotto, restituindo-se assim sua identidade e terminando uma busca de 36 anos.
}

\section{CANPHLAC}

Revista Eletrônica da ANPHLAC, ISSN 1679-1061, №. 18, p. 251-286, jan./jul. 2015. http://revista.anphlac.org.br/ 
desaparecida em 10 de dezembro de $1977 ;^{30}$ e é entregue no dia 10 de dezembro de cada ano, "Dia Internacional dos Direitos Humanos", reconhecendo cidadãos ou entidades que se destacaram por sua trajetória cívica na defesa dos direitos humanos. ${ }^{31}$ Em 2014, a homenageada foi Alicia Oliveira que, após ter seu cargo de juíza de menores revogado com o golpe de Estado de 24 de março de 1976, se dedicou à defesa de presos políticos e fez parte do grupo que criou, em 1979, o Centro de Estudios Legales y Sociales (CELS), organismo que se dedicou principalmente a levar à justiça a denúncia das violações cometidas pela última ditadura. ${ }^{32}$

Ao analisarmos os eventos oficiais ocorridos durante as comemorações em homenagem aos 31 anos de democracia ininterrupta na Argentina, podemos observar a presença reiterada do passado ditatorial. A participação de familiares de desaparecidos e de vítimas da repressão, na plateia e no próprio desenvolvimento das homenagens; a entrega de um prêmio que homenageia a luta em defesa dos direitos humanos; e a afirmação da busca por memória, verdade e justiça como um dos eixos centrais do projeto de Estado desenvolvido nos últimos 12 anos pelas sucessivas administrações kirchneristas são um demonstrativo de que, ao celebrar-se a democracia, celebravam-se também os avanços no tratamento dado ao legado da última ditadura e reconhecia-se a importância destes para a afirmação do regime democrático.

De acordo com Carlos Altamirano, há mais de duas décadas notam-se na Argentina vários debates relacionados entre si sobre o que ocorreu durante a mais recente ditadura civil-militar (1976-1983), como se ela se negasse a ficar no passado, tornando-se um "passado presente". Por outro lado, as "batalhas pela história" seriam

\footnotetext{
${ }^{30}$ Azucena Villaflor é considerada uma das fundadoras e uma das primeiras líderes das Madres de Plaza de Mayo. Após o desaparecimento de um de seus filhos, Azucena iniciou as gestões de busca por informações, durante as quais conheceu outras mulheres que também buscavam seus parentes desaparecidos. Deste grupo, juntaram-se 14 mães de desaparecidos que em 30 de abril de 1977 realizaram sua primeira manifestação ao redor da Plaza de Mayo. Em dezembro de 1977, Azucena trabalhava na elaboração coletiva de uma lista de desaparecidos. As reuniões que parte deste grupo realizava na igreja de Santa Cruz, em Buenos Aires, estavam infiltradas pelo capitão da Marinha, Alfredo Astiz, pertencente a um grupo de tarefas da ESMA. As informações brindadas por Astiz resultaram no sequestro e desaparecimento de Azucena, de duas madres, Teresa Careaga e María Ponce, e de outras pessoas que se mobilizaram em torno da lista de desaparecidos, publicada em 10 de dezembro no jornal La Nación.

31 Sobre o prêmio Azucena Villaflor, ver: http://www.jus.gob.ar/derechoshumanos/premio-azuzenavillaflor.aspx (Verificado em 25/01/2015).

${ }^{32}$ LANTOS, Nicolás. "Que nos explique cuál es el proyecto". Página/12, 14 Dez. 2014. Disponível em: http://www.pagina12.com.ar/diario/elpais/1-261948-2014-12-14.html (Verificado em 25/01/2015).
}

\section{GANPHLAC}

Revista Eletrônica da ANPHLAC, ISSN 1679-1061, Nº. 18, p. 251-286, jan./jul. 2015. http://revista.anphlac.org.br/ 
comuns na cultura política argentina: em outros momentos da história da vida civil no país, a representação do passado não permaneceu fixa, e os usos públicos dele se relacionaram à tomada de posicionamentos políticos. A singularidade do que acontece atualmente no país se relacionaria à magnitude e à natureza dos acontecimentos que seguiram ao golpe de Estado, principalmente o reconhecimento de que a ditadura instituiu um plano sistemático de repressão, como nunca visto antes no país (ALTAMIRANO, 2008, p. 18-19).

Entretanto, o reconhecimento da magnitude da violência por si só não explicaria a presença no presente do passado ditatorial argentino, ao ponto de este ser central na comemoração em homenagem ao aniversário da democracia. De acordo com Elizabeth Jelin, tal sentido ativo se relacionaria à dificuldade de gerar um consenso entre os diversos atores sociais sobre a sua significação. Em qualquer momento seria impossível encontrar uma memória, uma visão e interpretação únicas do passado compartilhadas por toda uma sociedade. Com as respectivas aberturas políticas, habilitou-se uma esfera pública na qual foram incorporadas, além do relato político dominante produzido pelas ditaduras, narrativas e relatos que até então estavam contidos na esfera privada e censurados. Logo, atores sociais diversos, com diferentes vínculos com a experiência passada, passaram a conviver sob o marco das regras do funcionamento democrático e a se enfrentar para afirmar como legítima e verdadeira sua versão do passado. Um desses atores é o Estado que, com a transição democrática, precisou incorporar para a sua agenda política o legado das violações aos direitos humanos, seja na busca de estratégias que respondam às expectativas sociais sobre possíveis medidas reparatórias ou nas tentativas de encerrar a questão (JELIN, 2002a).

No caso da Argentina, à primeira vista tais conflitos em torno do passado ditatorial parecem ter se resolvido após a eleição de Néstor Kirchner, em 2003. Se observarmos, por exemplo, as notícias que circulam nos meios de comunicação brasileiros sobre temas relativos à memória da última ditadura civil-militar argentina, $\mathrm{o}$ país vizinho geralmente surge como um "exemplo", reiterado sempre que uma importante causa judicial avança ou quando é restituída a identidade de um bebê apropriado. O encerramento dos conflitos não teriam se dado pela opção por uma superação, "uma virada de página", mas por um Estado que teria assumido a busca por

\section{GANPHLAC}

Revista Eletrônica da ANPHLAC, ISSN 1679-1061, №. 18, p. 251-286, jan./jul. 2015. http://revista.anphlac.org.br/ 
memória, verdade e justiça como um elemento central de suas políticas públicas e pelo reconhecimento local e internacional das medidas adotadas.

$\mathrm{Na}$ bibliografia recente sobre memórias da última ditadura civil-militar argentina, as medidas adotadas por Néstor Kirchner nos primeiros anos de seu mandato presidencial surgem como um "antes e depois" nas relações entre o Estado argentino e o passado ditatorial, principalmente devido a um conjunto de atos e atividades promovidos entre os anos de 2003 e 2006: o espaço dado a madres e abuelas de Plaza de Mayo na Casa Rosada e o reconhecimento de sua trajetória com prêmios e homenagens; a revogação das "leis de Perdão" e a retomada do processamento judicial de crimes de lesa-humanidade cometidos no período anterior (1973-1976) e durante a última ditadura; a transformação do complexo da Escuela Superior de Mecánica de la Armada (ESMA), onde funcionara um centro clandestino de detenção, em "espaço de memória"; a retirada das fotos dos ex-ditadores Jorge Rafael Videla e Reynaldo Bignone do panteão de membros célebres do Exército, no Colegio Militar de la Nación; o decreto de feriado nacional no dia 24 de março, "Día Nacional de la Memoria, por la Verdad y Justicia” (BISQUERT \& LVOVICH, 2008; Da SILVA CATELA, 2010; JELIN, 2010; BAUER, 2012).

Nesse sentido, Ludmila da Silva Catela aponta nos últimos anos para a circulação de "memórias dominantes", unidas em torno do repúdio e da denúncia do "terrorismo de Estado", produzidas principalmente pelos organismos de direitos humanos, que na atual conjuntura encontraram o Estado como interlocutor para suas reivindicações, inaugurando-se um período de "estatização da memória". Tal interlocução seria o resultado de uma mudança no papel desempenhado pelo Estado, pois este, ao reivindicar as memórias da última ditadura, passou a se posicionar como um agente comprometido com o passado recente, sem limitar sua política a instâncias formais de reconstrução da verdade e da justiça, atuando em espaços diretamente relacionados com os "tempos e calendários da memória" criados e defendidos pelos organismos e se utilizando de uma linguagem própria a eles (Da SILVA CATELA, 2010, p. 103-107).

Para Elizabeth Jelin, a mudança da postura do Estado argentino em relação às memórias da ditadura tornou-se pública durante as comemorações do 24 de março de

\section{GANPHLAC}

Revista Eletrônica da ANPHLAC, ISSN 1679-1061, №. 18, p. 251-286, jan./jul. 2015. 
2004, principalmente por meio do papel central desempenhado pelo presidente no ato realizado na ex-ESMA e pelo discurso proferido por ele, em que apelou para sua experiência pessoal e grupos de pertencimento juvenis como elementos de solidariedade, de compromisso e de vinculação com o tema. Em um discurso dirigido para familiares de desaparecidos que participavam da cerimônia, Néstor Kirchner fez poucas referências à sua presença ali como presidente, e exaltou seu pertencimento à geração dos desaparecidos, "companheiros" de militância na esquerda peronista (JELIN, 2010, p. 243-245).

De acordo com Caroline Silveira Bauer, a diferença do governo de Néstor Kirchner em relação a seus antecessores seria a "vontade política" de adotar "políticas de memória"; de reconhecer e incorporar as reinvindicações das vítimas e dos organismos de direitos humanos; e de torná-las centrais na sua administração. Para tanto, houve o esforço para construir uma nova e renovada "institucionalidade", a partir de medidas que resultaram principalmente em uma garantia de acesso à justiça:

$\mathrm{Na}$ verdade, foi resultado de um longo processo, que abrangeu uma troca na composição da Corte Suprema de Justiça, mediante uma avaliação de seus antigos membros e sua substituição por outros juízes; a ratificação da convenção sobre a imprescritibilidade dos crimes de lesa humanidade; e, por fim, a declaração de nulidade, por inconstitucionalidade, das leis citadas acima [Punto Final e Obediencia Debida], assim como dos indultos conferidos por Carlos Menem a civis e militares implicados com a estratégia de implantação do terror da ditadura civil-militar argentina (BAUER, 2012, p. 304).

Um dos elementos centrais que corroboram o argumento da "exemplaridade" argentina seria a aplicação da justiça no processamento contra repressores. Estes foram retomados a partir de 2006, quando a Cámara de Casación Penal, máximo tribunal penal da Argentina, considerou que os Indultos eram inconstitucionais. No ano anterior, a Corte Suprema de Justicia já havia decretado a anulação das leis de Punto Final e de Obediencia Debida por considerá-las inconstitucionais (MEMORIA ABIERTA, 2010, p. 134-141). Desde então já foram realizados 133 julgamentos por "crimes de lesahumanidade", com 613 condenações, segundo dados do Ministerio de Justicia y

\section{CANPHLAC}

Revista Eletrônica da ANPHLAC, ISSN 1679-1061, №. 18, p. 251-286, jan./jul. 2015. http://revista.anphlac.org.br/ 
Derechos Humanos. ${ }^{33}$ Além do seu valor como política reparatória, os julgamentos têm avançado na investigação e divulgação de informação sobre temas que costumam ficar de fora nas abordagens acerca da última ditadura civil-militar. Algumas das causas, por exemplo, não acusam apenas os militares, buscam esclarecer a participação de uma ampla gama de civis na repressão, como, por exemplo, empresários, médicos e oficiais de justiça. ${ }^{34}$

Aos avanços no exercício da justiça soma-se a vinculação entre Estado e organismos de direitos humanos, principalmente os conformados por familiares de desaparecidos. Tanto Néstor Kirchner quanto Cristina Kirchner em seus discursos públicos reconheceram o valor da luta dos familiares e o seu exemplo para o exercício da cidadania. Durante o ato oficial realizado em 24 de março de 2006 no Colegio Militar de la Nación, Néstor Kirchner terminou seu discurso com uma homenagem às Madres e Abuelas de Plaza de Mayo: "En el momento más terrible de la noche de la dictadura, fueron hombres y mujeres, pero sobre todo mujeres, las que se organizaron para enfrentar la barbárie.". ${ }^{35}$ Em dezembro de 2010, durante as comemorações do $27^{\circ}$ aniversário da democracia, Cristina Kirchner entregou o Premio Bincentenario a Angela Boitano, Marta Vázquez, Laura Conte, Hebe de Bonafini e Estela de Carlotto; todas, mães de desaparecidos e militantes de distintos organismos de direitos humanos. Após a entrega, ressaltou sua admiração por elas, não apenas por sua luta, mas também por nunca terem recorrido à violência. ${ }^{36}$

Tal reconhecimento se expressa também na nomeação de militantes de direitos humanos para cargos no Executivo, como, por exemplo, a escolha de Martín Fresnada, em 2012, para secretário de Direitos Humanos do governo nacional. Filho de Tomás Fresnada e María de las Mercedes Argñaraz, sequestrados e desaparecidos em julho de

33 BARRERA, Laureano. El juzgamiento a la represión ilegal: qué juicios habrá este año. Infojus Noticias, 06 jan. 2015. Disponível em: http://www.infojusnoticias.gov.ar/nacionales/el-juzgamiento-a-larepresion-ilegal-que-juicios-habra-este-ano-7033.html (Verificado em: 25/01/2015).

${ }^{34}$ MANNARINO. Juan Manuel. Las nuevas líneas de investigación que se abren en los juicios de lesa. Infojus Noticias, 06 jan. 2015. Disponível em: http://www.infojusnoticias.gov.ar/nacionales/las-nuevaslineas-de-investigacion-que-se-abren-en-los-juicios-de-lesa-7037.html (Verificado em: 25/01/2015).

35 PIQUÉ, Martín. "No han sufrido castigo alguno". Página/12, 25 mar. 2006. Disponível em: http://www.pagina12.com.ar/diario/elpais/1-64719-2006-03-25.html (Verificado em: 25/01/2015).

${ }^{36}$ MEYER, Adriana. Antes de abrir la boca, abramos la cabeza. Página/12, $11 \mathrm{dez} .2010$. Disponível em: http://www.pagina12.com.ar/diario/elpais/1-158496-2010-12-11.html (Verificado em: 25/01/2015).

\section{GANPHLAC}

Revista Eletrônica da ANPHLAC, ISSN 1679-1061, Nº. 18, p. 251-286, jan./jul. 2015. http://revista.anphlac.org.br/ 
1977, Martín Fresnada é um dos fundadores de Hijos por la Identidad y la Justicia contra el Olvido y el Silencio (H.I.J.O.S), em Córdoba; atuou como advogado nos julgamentos realizados na cidade; e sua avó, Otilia Argañaraz, foi uma das dirigentes locais de Abuelas, até a morte. Logo, ao ocupar o posto máximo de promoção e defesa dos direitos humanos no Executivo, foram reconhecidas suas filiações pessoais e políticas com o tema, ressaltadas por ele em seu discurso durante a cerimônia de posse: "Fui uno de los tantos chicos criados en los locales de los organismos de derechos humanos. Esa es mi lucha”. 37

A esse reconhecimento, os familiares costumam responder expressando sua gratidão. Ao ser homenageada junto com outras madres no Museo Malvinas e Islas del Atlático Sur, Hebe de Bonafini, presidenta da Asociación Madres de Plaza de Mayo, por exemplo, afirmou: "Néstor y Cristina nos dieron la felicidad que nos faltaba."38 A gratidão é fruto também da adoção pelo Estado argentino de demandas e práticas rememorativas próprias do movimento argentino pelos direitos humanos, como, por exemplo, o reconhecimento oficial das datas que formam o "calendário de comemorações da ditadura". Em 2006, tanto o 24 de março quanto o 02 de abril, "Día del Veterano y de los caídos en la Guerra de Malvinas", foram declarados feriados nacionais; em 2014, foi instituído o "Día Nacional de la Juventud” no 16 de setembro, em comemoração à denominada "Noche de los lápoces". ${ }^{39}$ Esta data relaciona-se ainda a uma preocupação pela transmissão da experiência da ditadura às futuras gerações, por meio da promoção de práticas educativas pelo Ministerio de Educación .

\footnotetext{
${ }^{37}$ GINZBERG, Victoria. Por los derechos del pasado y del futuro. Página/12, 16 maio 2012. Disponível em: http://www.pagina12.com.ar/diario/elpais/1-194151-2012-05-16.html (Última verificação em: 25/01/2015); VALES, Laura. Un hijo en la Secretaría de Derechos Humanos. Página/12, 16 maio 2012. Disponível em: http://www.pagina12.com.ar/diario/elpais/1-194048-2012-05-15.html (Última verificação: $28 / 01 / 2015$ ).

${ }^{38}$ Homenajearon a Hebe de Bonafini en el Museo Malvinas de la Ex Esma. TÉLAM, 20 dez. 2014. Disponível em: http://www.telam.com.ar/notas/201412/89576-homenajearon-a-hebe-de-bonafini-en-elmuseo-malvinas-de-la-ex-esma.html (última verificação em: 25/01/2015).

39 "La noche de los lápices" é o nome pelo qual se tornaram célebres os procedimentos repressivos ocorridos durante o mês de setembro de 1976, quando foi sequestrado na cidade de La Plata um grupo de estudantes secundaristas como parte da repressão ao movimento estudantil, dentre os quais estavam: Francisco López Muntaner, María Claudia Falcone, Claudio de Acha, Horacio Ángel Ungaro, Daniel Alberto Racero, María Clara Ciocchini, Pablo Díaz, Patrícia Miranda, Gustavo Calloti e Emilce Moler. A maioria deles era de militantes da Unión de Estudiantes Secundarios (UES), uma das frentes de massa dos Montoneros, com exceção de Pablo Díaz, integrante da Juventud Guevarista (JG); e Patricia Miranda, sobre a qual não temos informações a respeito de sua vinculação com qualquer organização política. Desse grupo, somente os quatro últimos sobreviveram.
}

\section{GANPHLAC}

Revista Eletrônica da ANPHLAC, ISSN 1679-1061, Nº. 18, p. 251-286, jan./jul. 2015. http://revista.anphlac.org.br/ 
Soma-se a estes a promoção de espaços nos quais alguns organismos deem continuidade a seu trabalho e preservem a memória da sua história de militância. No projeto de apropriação e ressignificação da ex-ESMA, por exemplo, alguns edifícios ficaram sob o cuidado dos organismos de direitos humanos. Assim, Familiares de Detenidos y Desaparecidos por Razones Políticas ocuparam o prédio "30.000 Compañeros Presentes", transferindo seu arquivo institucional para o local, em um trabalho conjunto com Memoria Abierta.$^{40}$ Em 24 de março de 2014 foi inaugurada a Casa por la Identidad, nova sede de Abuelas. Para Estela de Carlotto, esta inauguração significou um "sonho cumprido" de "transformar estes lugares cheios de horror", “conquista alcançada apenas com a valentia e decisão de Néstor Kichner". ${ }^{4}$

Como afirmamos anteriormente, à primeira vista o reconhecimento mútuo entre Estado e alguns organismos de direitos humanos parecem apontar para a resolução dos conflitos pela memória na Argentina. Porém, de acordo com Ludmila da Silva Catela, frente a esse processo de "estatização da memória" surge o questionamento para as suas consequências e para o risco da cristalização de certas formas de memórias que “[...] 'legimitadas' por el Estado y 'autorizadas' por los familiares de las víctimas, puedan opacar otros relatos más débiles, menos visibles, más periféricos y subterráneos" (Da SILVA CATELA, 2010, p. 106). Portanto, chama atenção para os possíveis esquecimentos e silêncios que formam e legitimam a "memória dominante" que atualmente circula sobre o passado ditatorial. Nesse sentido, por exemplo, apesar de o Estado ter adotado a necessidade de que a escola seja a principal instituição para se garantir o "nunca mais", ao analisar os materiais produzidos pelo Ministerio de Educación, em 2006, a autora nota a exclusão no relato sobre o passado recente da

\footnotetext{
${ }^{40}$ Formado pela Asamblea Permanente por los Derechos Humanos (APDH), pelo Centro de Estudios Legales y Sociales (CELS), pela Fundación Memoria Histórica y Social Argentina, pela Madres de Plaza de Mayo Línea Fundadora, pela Familiares de Desaparecidos y Detenidos por Razones Políticas, pela Comisión de Familiares, Sobrevivientes y Compañeros de las Víctimas del Vesubio e pelo Servicio de Paz y Justicia (SERPAJ), o Memoria Abierta produziu um arquivo oral que disponibiliza as gravações de entrevistas com pessoas que têm diferentes vínculos com o passado ditatorial, entre as quais se encontram 192 entrevistas de sobreviventes de centros clandestinos de detenção.

41 "ESMA: "diez años después la lucha no está terminada"'. Infojus Notícias, 25 mar. 2014. Disponível em:http://infojusnoticias.gov.ar/nacionales/esma-diez-anos-despues-la-lucha-no-esta-terminada3561.html (Verificado em: 25/01/2015).
}

\section{CANPHLAC}

Revista Eletrônica da ANPHLAC, ISSN 1679-1061, Nº. 18, p. 251-286, jan./jul. 2015. http://revista.anphlac.org.br/ 
discussão sobre a violência política dos anos 1970, a luta armada e os grupos guerrilheiros (Da SILVA CATELA, p. 107-109).

A análise de Ludmila da Silva Catela aponta ainda para a importância de se observar a interação, geralmente conflituosa, entre a "memória dominante" e outros relatos, principalmente devido às distintas expectativas futuras que a produção de relatos do passado no presente costuma gerar. Dessa maneira, apesar de alguns organismos de direitos humanos apoiarem as medidas adotadas pelo Estado nos últimos 12 anos e serem publicamente gratos a elas, não podemos afirmar que há hoje uma concordância no interior do movimento, nem que todas as demandas foram cumpridas.

Em 24 de março de 2011, o jornal Página/12 publicou um suplemento especial dedicado aos organismos de direitos humanos. Em um dos textos, a Asociación de Ex Detenidos Desaparecidos (AEDD), organismo formado em 1984 por sobreviventes dos centros clandestinos de detenção, denunciou que "lamentavelmente", a partir da eleição de Néstor Kirchner, dirigentes de direitos humanos abriram mão de sua "absoluta independência" e "se alinharam ao governo" ao ponto de ser mais frequente sua participação em atos e campanhas oficias do que em "espaços de luta do povo", "gerando uma cegueira" frente às atuais violações de direitos humanos. ${ }^{42}$

O mesmo pode ser dito em relação ao desenvolvimento das causas judiciais. Nesse sentido, HIJOS La Plata ${ }^{43}$ defende que nos últimos nove anos o que houve no país foi uma Justiça que funcionou "a conta gotas", pois julgaram-se apenas as responsabilidades das altas chefias militares ou policiais, sem se contemplar a totalidade de repressores que atuaram em cada centro clandestino de detenção nem a totalidade de vítimas que por eles passaram:

Curiosamente venimos escuchando desde los sectores oficialistas que cada año que se inicia será realmente "el año de los juicios", valoración propia de quien analiza en abstracto el proceso en lugar de ir a los números concretos. Si tomamos los últimos 5 años veremos

\footnotetext{
${ }^{42}$ CALVO, Adriana. No a la impunidad de ayer y de hoy. Página/12 24 mar. 2011. Disponível em: http://www.pagina12.com.ar/diario/especiales/subnotas/18-38955-2009-03-24.html (Verificado em: 28/01/2015).

${ }^{43}$ A utilização do nome da organização varia alternativamente entre HIJOS e H.I.J.O.S. O uso da sigla sem pontos responde a uma decisão da regional de La Plata que pretendia ter autonomia em relação com a rede nacional que reúne as outras regionais, e a uma atitude política mais radical por parte dela, apesar de reconhecer os objetivos colocados na sigla (RÚA, 2005, p. 196).
}

\section{GANPHLAC}

Revista Eletrônica da ANPHLAC, ISSN 1679-1061, Nº. 18, p. 251-286, jan./jul. 2015. http://revista.anphlac.org.br/ 
que lejos de crecer exponencialmente, el proceso anual de juzgamiento se va estancando en dos decenas de juicios con un centenar y medio de condenas cada año. ${ }^{44}$

Somam-se a esta as críticas devido às constantes intimidações contra testemunhas. O caso mais notório foi o segundo desaparecimento de Jorge Julio López, na cidade de La Plata. Sequestrado em outubro de 1976, Julio López esteve desaparecido em diversos centros clandestinos da província de Buenos Aires até ser posto em liberdade, em junho de 1979. Em 2006, participou da primeira causa contra um repressor - Miguel Osvaldo Etchecolatz, ex-Diretor Geral de Investigações da Polícia da Província de Buenos Aires -, e sua declaração envolvia mais de 60 militares e policiais nos crimes cometidos. Na madrugada do dia em que se anunciaria a condenação, 18 de setembro de 2006, Julio López desapareceu após deixar sua residência, e até o momento seu caso não foi esclarecido. Para alguns denunciantes do movimento pelos direitos humanos, Julio López seria, junto com outras vítimas de ações policiais, "um dos desaparecidos da democracia" e o exemplo da ineficácia e do exercício parcial de Justiça do governo. ${ }^{45}$ Consequentemente, em maio de 2014 foi apresentada uma denúncia na Comisión Interamericana de Derechos Humanos (CIDH) contra o Estado argentino por sua responsabilidade direta no impedimento para que se avance a investigação e se esclareça o segundo sequestro e desaparecimento de Julio López. $^{46}$

A ocupação e ressignificação da ex-ESMA tampouco é um processo livre de conflitos. Em janeiro de 2014, a área de imprensa de HIJOS La Plata publicou detalhes do "museu da memória" que a Secretaria de Derechos Humanos pretendia implantar no prédio do Casino de Oficiales, criticando as intervenções que seriam feitas no espaço original e o plano museológico que apontava para uma banalização do local, por

\footnotetext{
${ }^{44}$ PRENSA HIJOS. Haciendo la plancha. Balance 2014 de los juicios a los Genocidas. Disponível em: http://hijosprensa.blogspot.com.br/2014/11/haciendo-la-plancha.html (Verificado em: 28/01/2015).

${ }_{45}$ PRENSA HIJOS. 8 años sin Lopez. Disponível em: http://hijosprensa.blogspot.com.br/2014/09/a-8anos-sin-lopez.html (Verificado em: 28/01/2015).

${ }^{46}$ BULLENTINI, Ailín. La desaparición de López, ante la CIDH. Página/12, 07 maio 2014. Disponível em: http://www.pagina12.com.ar/diario/elpais/1-245670-2014-05-07.html (Verificado em: 28/01/2015).
}

\section{CANPHLAC}

Revista Eletrônica da ANPHLAC, ISSN 1679-1061, №. 18, p. 251-286, jan./jul. 2015. 
convertê-lo, em suas próprias palavras, numa "Disneylandia". 47 Osvaldo Barros, que esteve sequestrado na ESMA entre agosto de 1979 e fevereiro de 1980, expressou opinião similar ao falar em nome da AEDD: “[...] en nuestra opinión esto le va a quitar todo el sentido a lo que ahí ocurrió. Se va a ir transformando en un show mediático." Outro sobrevivente da ESMA e membro da AEDD, Carlos Lordkipanidse, apontou que o projeto seria parte da "desnaturalização que se deu ao conjunto da ESMA", "uma ressignificação oriunda do governo" que busca fazer da ex-ESMA "um lugar de vida e alegria", "[...] cuando en realidad eso pasa por encima de los sentimientos de por lo menos cinco mil familiares directos de las víctimas que pasaron por ese lugar". ${ }^{48}$

Deve-se pontuar que o projeto de museu da ex-ESMA aponta que a proposta final teria sido "fruto do consenso", após apresentações feitas aos organismos de direitos humanos e a sobreviventes. Porém, as reações ao mesmo apontam não só para uma discordância com o que se pretende fazer no espaço, mas com a ocupação da exESMA como um todo, em um demonstrativo de que na Argentina os conflitos pela memória não se encerraram ou foram superados com uma maior vinculação do Estado com o passado ditatorial nem com o exercício da Justiça. As relações que no presente se estabelecem com a última ditadura civil-militar são diversas, assim como as expectativas, desejos e demandas com o tratamento que deve ser dado a suas marcas individuais e coletivas. Memória, esquecimento e silêncio são elementos que conformam a "memória dominante" sustentada pelo Estado e por parte das vítimas e dos organismos de direito humanos, assim como os outros relatos que surgem de locais menos legitimados, gerando enfrentamentos simbólicos e reais, oposições irreconciliáveis e exclusões na conformação de uma memória pública do recente passado ditatorial na Argentina.

\section{Considerações finais}

\footnotetext{
${ }^{47}$ PRENSA HIJOS. Museo del Casino de Oficiales de la ESMA. La Disneylandia de Fresnada y Parrilli. Disponível em: http://hijosprensa.blogspot.com.br/2014/01/museo-del-casino-de-oficiales-de-laesma.html (Última verificação em: 28/01/2015).

${ }^{48}$ LA RETAGUARDIA. Informe Especial: el proyecto de nuevo museo em la ESMA y las voces de los sobrevivientes. La Retaguardia, 31 jan. 2014. Disponível em: http://www.laretaguardia.com.ar/2014/01/informe-especial-el-proyecto-de-nuevo.html (Verificado: 28/01/2015).
}

\section{CANPHLAC}

Revista Eletrônica da ANPHLAC, ISSN 1679-1061, № 18, p. 251-286, jan./jul. 2015. 
Os estudos acerca das ditaduras civis-militares no Cone Sul demostram que este é um campo de investigações consolidado. No caso brasileiro, por exemplo, os 50 anos do golpe de 1964 foram relembrados com a realização de seminários em diversas universidades do País. Acompanhando os debates realizados, podemos perceber que alguns temas foram recorrentes: as discussões em torno da interpretação da Lei de Anistia; as características da transição democrática; os legados da ditadura; e, sobretudo, a discussão acerca da participação civil, não apenas na articulação do golpe, mas no financiamento de centros de extermínio e na expressão de consentimento com o projeto político do regime ditatorial. A realização desses eventos e a reafirmação de políticas públicas, tanto as que já haviam sido instauradas anteriormente quanto as que surgiram na conjuntura dos 50 anos, são indicativos das tentativas, mesmo que parciais e incompletas, das reparações dos danos cometidos. Nesse sentido, afirmar que o Brasil seria o país do esquecimento no que diz respeito ao tratamento das violações de direitos humanos desconsidera não apenas as iniciativas governamentais levantadas anteriormente, mas, sobretudo, a presença e atuação marcante dos familiares dos mortos e desaparecidos na busca por memória, verdade e justiça.

No caso argentino, a reivindicação da memória, como consigna de movimentos sociais e como catalisadora de políticas oficiais, e a ausência de uma política nacional de arquivos podem ser apontados como alguns dos motivos que fazem das memórias um dos objetos privilegiados de análise nos estudos sobre a última ditadura civil-militar. Tais trabalhos geralmente abordam os discursos produzidos durante a própria ditadura, a partir dos quais se formam algumas das representações produzidas posteriormente, e os modos como ao longo da democracia estas representações foram se transformando e interagindo com outras em um campo de conflitos, o que resultou, em geral, no silenciamento de questões sensíveis ou indesejadas. A partir deles podemos problematizar o quadro argentino atual, de uma aparente superação dos conflitos de memória, ao demonstrar que há uma diversidade de memórias produzidas e de demandas para o tratamento do legado das violações aos direitos humanos. Logo, contribuem para o questionamento que fizemos no presente artigo de que na Argentina, assim como em outros países da região, memória e esquecimento se fazem presentes,

\section{GANPHLAC}

Revista Eletrônica da ANPHLAC, ISSN 1679-1061, №. 18, p. 251-286, jan./jul. 2015. http://revista.anphlac.org.br/ 
mesmo num momento em que o questionamento sobre como lidar com o passado ditatorial à primeira vista já teria sido respondido.

A proposta deste artigo, portanto, não foi realizar uma análise comparativa entre os casos brasileiro e argentino, mas problematizar o lugar comum reproduzido de forma recorrente quando as duas experiências ditatoriais são contrapostas: a de que o Brasil seria o país do esquecimento, enquanto a Argentina seria o país da memória. Contraposição esta que deixa de lado os paradoxos presentes na relação que ambos os países estabelecem com o passado ditatorial. Baseia-se, sobretudo, a nosso ver, em uma relação direta entre a aplicação da justiça para julgar os crimes cometidos durante a ditadura como garantia de preservação de uma memória de negação do autoritarismo e da violência. Certamente não questionamos a importância do exercício da justiça e seu caráter condenatório e reparador. Entretanto, enquanto o caso argentino demonstra que a aplicação da Justiça não gerou um consenso em torno da ressignificação da ditadura nem evitou a perpetuação de novas violações, o brasileiro demonstra que também se produz memória e reparação além dos tribunais.

\section{CANPHLAC}

Revista Eletrônica da ANPHLAC, ISSN 1679-1061, №. 18, p. 251-286, jan./jul. 2015. http://revista.anphlac.org.br/ 


\section{Fontes}

Fundo SNI. Arquivo Nacional

\section{Legislação}

BRASIL. Lei n. 6.683, de 28 de agosto de 1979. Concede anistia e dá outras providências. Disponível em: <http://www.planalto.gov.br/ccivil_03/leis/L6683.htm>. Verificado em 24/01/2015.

\section{Endereços eletrônicos consultados}

http://www.jus.gob.ar/derechoshumanos/premio-azuzena-villaflor.aspx Verificado em 25/01/2015.

http://www.mdhm.rs.gov.br/conteudo/971/sobre-o-museu Verificado em: 25/01/2015.

http://www.stf.jus.br/arquivo/cms/noticiaNoticiaStf/anexo/ADPF153.pdf. Verificado em 30/01/2015.

http://www.biblioteca.presidencia.gov.br/ex-presidentes/jb-figueiredo/discursos-deposse/discurso-de-posse/view. Verificado em 24/01/2015.

http://portal.mj.gov.br/data/Pages/MJABFF735EITEMIDF6425A864D1448ACB9FC7 B3A1CDC1022PTBRNN.htm Verificado em 24/01/2015.

http://portal.sdh.gov.br/.arquivos/livrodireitomemoriaeverdadeid.pdf. Verificado em 24/01/2015.

http://www.memoriasreveladas.arquivonacional.gov.br/cgi/cgilua.exe/sys/start.htm?tpl= home. Verificado em 24/01/2015.

http://www.cnv.gov.br/index.php/outros-destaques/574-conheca-e-acesse-o-relatoriofinal-da-cnv Verificado em 30/01/2015.

\section{Bibliografia}

ABRÃO, Paulo. 24 Caravana Anistia Camponeses do Araguaia. Boletim da Comissão de Anistia - Ministério da Justiça, ano III, n. 36, jul. 2009.

ABRÃO, Paulo; TORELLY, Marcelo. O programa de reparações como eixo estruturante da justiça de transição no Brasil. In: Justiça de transição: manual para a América Latina. Brasília: Comissão de Anistia, Ministério da Justiça; Nova Iorque: Centro Internacional para a Justiça de Transição, 2011.

ALTAMIRANO, Carlos. Pasado presente. In: YAKLEVICH, Pablo (comp.) [et.al.]. Argentina, 1976. Estudios en torno al golpe de estado. Buenos Aires: FCE, 2008.

\section{CANPHLAC}

Revista Eletrônica da ANPHLAC, ISSN 1679-1061, №. 18, p. 251-286, jan./jul. 2015. 
ARAÚJO, Maria Paula. Memória, testemunho e superação: história oral da anistia no Brasil. História Oral, v. 15, n. 2, p. 11-31, jul.-dez. 2012.

BARRERA, Laureano. El juzgamiento a la represión ilegal: qué juicios habrá este año. Infojus Noticias, 06 jan. 2015. Disponível em: http://www.infojusnoticias.gov.ar/nacionales/el-juzgamiento-a-la-represion-ilegal-quejuicios-habra-este-ano-7033.html (Última verificação em: 25/01/2015).

BAUER, Caroline S. Brasil e Argentina: ditaduras, desaparecimentos e políticas de memória. Porto Alegre: Medianiz, 2012.

BISQUERT, Jacquelina \& LVOVICH, Daniel. La cambiante memoria de la dictadura: discursos públicos, movimientos sociales y legitimidad democrática. Buenos Aires: Biblioteca Nacional, 2008.

BRASIL, Vera Vital. Dano e reparação no contexto da Comissão da Verdade: a questão do testemunho. In: Revista Anistia Política e Justiça de Transição. Brasília: Ministério da Justiça, n. 6, 2012.

BRITO, Alexandra Barahona de. Justiça transicional e a política da memória: uma visão global. In: Revista Anistia Política e Justiça de Transição. Brasília: Ministério da Justiça, n. 1, 2009.

BULLENTINI, Ailín. La desaparición de López, ante la CIDH. Página/12, 07 maio 2014. Disponível em: http://www.pagina12.com.ar/diario/elpais/1-245670-2014-0507.html (Verificado em: 28/01/2015).

CALVO, Adriana. No a la impunidad de ayer y de hoy. Página/12 24 mar. 2011. Disponível em: http://www.pagina12.com.ar/diario/especiales/subnotas/18-38955-200903-24.html (Verificado em: 28/01/2015).

COMISSÃO DE FAMILIARES DE MORTOS E DESAPARECIDOS POLÍTICOS; IEVE. Dossiê ditadura: mortos e desaparecidos políticos no Brasil (1964-1985). São Paulo: Imprensa Oficial do Estado de São Paulo, 2009.

CONGRESSO NACIONAL. Comissão Mista sobre Anistia. Anistia. Brasília: [Centro Gráfico do Senado Federal], 1982, 2 v.

Da SILVA CATELA, Ludmila. Pasados en conflicto. De memorias dominantes, subterráneas y denegadas. In: BOHOLAVSKY, Ernesto [et.al.]. Problemas de la historia reciente del Cono Sur. Volumen I. Buenos Aires: Prometeo, 2010.

"ESMA: 'diez años después la lucha no está terminada'". Infojus Notícias, 25 mar. 2014. Disponível em: http://infojusnoticias.gov.ar/nacionales/esma-diez-anos-despuesla-lucha-no-esta-terminada-3561.html (Verificado em: 25/01/2015).

\section{GANPHLAC}

Revista Eletrônica da ANPHLAC, ISSN 1679-1061, Nº. 18, p. 251-286, jan./jul. 2015. http://revista.anphlac.org.br/ 
FERREIRA BASTOS, Lucia Elena Arantes. A anistia brasileira em comparação com as da América Latina: uma análise na perspectiva do direito internacional. TELES, Edson; TELES, Janaína de Almeida (org.). Desarquivando a ditadura: memória e justiça no Brasil, v. II. São Paulo: HUCITEC, 2009.

FICO, Carlos. A negociação parlamentar da anistia de 1979 e o chamado 'perdão aos torturadores'. Revista Anistia Política e Justiça de Transição. Brasília: Ministério da Justiça, 2011, v. 4.

GINZBERG, Victoria. Por los derechos del pasado y del futuro. Página/12, 16 maio 2012. Disponível em: http://www.pagina12.com.ar/diario/elpais/1-194151-2012-0516.html (Última verificação em: 25/01/2015).

GONÇALVES, Daniele Nilin. O preço do passado: anistia e reparação de perseguidos políticos no Brasil. São Paulo: Expressão Popular, 2009.

GRECO, Heloísa Bizoca. Dimensões fundacionais da luta pela anistia. Tese (Doutorado em História) - Faculdade de Filosofia e Ciências Humanas, Universidade Federal de Minas Gerais, Belo Horizonte, 2003.

Homenajearon a Hebe de Bonafini en el Museo Malvinas de la Ex Esma. TÉLAM, 20 dez. 2014. Disponível em: http://www.telam.com.ar/notas/201412/89576homenajearon-a-hebe-de-bonafini-en-el-museo-malvinas-de-la-ex-esma.html (última verificação em: 25/01/2015).

JELIN, Elizabeth. Los trabajos de la memoria. Buenos Aires: Siglo XXI, 2002a. . (comp.). Las conmemoraciones: las disputas en las fechas "infelices”. Madrid: Siglo XXI, 2002b.

- ¿Víctimas, familiares o ciudadano/as? Las luchas por la legitimidad de la palabra. In: CRENZEL, Emilio (coord.). Los desaparecidos en la Argentina: memorias, representaciones e ideas: 1983-2008. Buenos Aires: Biblos, 2010.

KIRALY, Letícia. Encontro Internacional sobre impacto da ditadura reúne especialistas na Capital. Portal do Governo do Estado do Rio Grande do Sul, Porto Alegre, 14. Nov. 2014. http://www.rs.gov.br/conteudo/207132/encontro-internacional-sobre-impacto-daditadura-reune-especialistas-na-capital (Verificado em 24/01/2015).

LA RETAGUARDIA. Informe Especial: el proyecto de nuevo museo em la ESMA y las voces de los sobrevivientes. La Retaguardia, 31 jan. 2014. Disponível em: http://www.laretaguardia.com.ar/2014/01/informe-especial-el-proyecto-de-nuevo.html (Verificado: 28/01/2015).

LANTOS, Nicolás. Que nos explique cuál es el proyecto. Página/12, 14 Dez. 2014. Disponível em: http://www.pagina12.com.ar/diario/elpais/1-261948-2014-12-14.html (Verificado em 25/01/2015).

\section{GANPHLAC}

Revista Eletrônica da ANPHLAC, ISSN 1679-1061, Nº. 18, p. 251-286, jan./jul. 2015. http://revista.anphlac.org.br/ 
MANNARINO. Juan Manuel. Las nuevas líneas de investigación que se abren en los juicios de lesa. Infojus Noticias, 06 jan. 2015. Disponível em: http://www.infojusnoticias.gov.ar/nacionales/las-nuevas-lineas-de-investigacion-que-seabren-en-los-juicios-de-lesa-7037.html (Última verificação em: 25/01/2015).

MEMORIA ABIERTA. Abogados, derecho y política. Buenos Aires: Memoria Abierta, 2010.

MEYER, Adriana. Antes de abrir la boca, abramos la cabeza. Página/12, 11 dez. 2010. Disponível em: http://www.pagina12.com.ar/diario/elpais/1-158496-2010-12-11.html (Verificado em: 25/01/2015).

MEZAROBBA, Glenda. Um acerto de contas com o futuro - a anistia e suas consequências: um estudo do caso brasileiro. São Paulo: Humanitas/Fapesp, 2006.

MINISTÉRIO DA JUSTIÇA. Revista Anistia Política e Justiça de Transição, n. 1. Brasília: Ministério da Justiça, jan.-jun. 2009.

NEPOMUCENO, Eric. Direitos humanos e a verdade: lições que não quisemos aprender. Carta $\quad$ Capital, $03 . \quad 011$. http://cartamaior.com.br/?\%2FEditoria\%2FDireitos-Humanos\%2FDireitos-humanos-ea-verdade-licoes-que-nao-quisemos-aprender\%0D\%0A\%2F5\%2F17748 (Verificado em 24/11/2015).

PAPALEO, Cristina. Argentina é considerada exemplo na luta contra a impunidade. Deutsche Welle, 30. Nov. 2011. http://www.dw.de/argentina-\%C3\%A9-consideradaexemplo-na-luta-contra-a-impunidade/a-15564399 (Verificado em 24/01/2015).

PIQUÉ, Martín. "No han sufrido castigo alguno". Página/12, 25 mar. 2006. Disponível em: http://www.pagina12.com.ar/diario/elpais/1-64719-2006-03-25.html (Última verificação em: 25/01/2015).

PRENSA HIJOS. "8 años sin Lopez. Disponível em: http://hijosprensa.blogspot.com.br/2014/09/a-8-anos-sin-lopez.html (Verificado em: 28/01/2015).

PRENSA HIJOS. Haciendo la plancha. Balance 2014 de los juicios a los Genocidas. Disponível em: http://hijosprensa.blogspot.com.br/2014/11/haciendo-la-plancha.html (Verificado em: 28/01/2015).

PRENSA HIJOS. Museo del Casino de Oficiales de la ESMA. La Disneylandia de Fresnada y Parrilli. Disponível em: http://hijosprensa.blogspot.com.br/2014/01/museodel-casino-de-oficiales-de-la-esma.html (Última verificação em: 28/01/2015).

PRESIDENCIA DE LA NACIÓN ARGENTINA. Acto por el $31^{\circ}$ aniversario de la Democracia y Día Internacional de los Derechos Humanos: Palabras de la Presidenta de la Nación. Disponível em: http://www.presidencia.gob.ar/discursos/28270-acto-por-el-

\section{GANPHLAC}

Revista Eletrônica da ANPHLAC, ISSN 1679-1061, Nº. 18, p. 251-286, jan./jul. 2015. 
31o-aniversario-de-la-democracia-y-dia-internacional-de-s-derechos-humanos-palabrasde-la-presidenta-de-la-nacion (Verificado em 25/01/2015).

RESENDE, Pâmela de Almeida. Os vigilantes da ordem: a cooperação DEOPS/SP $e$ SNI e a suspeição aos movimentos pela anistia. (1975-1983). Rio de Janeiro: Arquivo Nacional, 2015 [no prelo].

RODEGHERO, Carla Simone; DIENSTMANN, Gabriel; TRINDADE, Tatiana. Anistia ampla, geral e irrestrita: história de uma luta inconclusa. Santa Cruz do Sul: Edunisc, 2011.

RÚA, Santiago Cueto. HIJOS La Plata: la democracia en cuestión. Tensiones entre el discurso de HIJOS y la legalidad democrática In: Anuario $N^{o} 20$, Escuela de Historia. Rosario: Homo Sapiens ed., 2005.

VALES, Laura. Un hijo en la Secretaría de Derechos Humanos. Página/12, 16 maio 2012. Disponível em: http://www.pagina12.com.ar/diario/elpais/1-194048-2012-0515.html (Última verificação: 28/01/2015).

TELES, Edson. Brasil e África do Sul: os paradoxos da democracia. Memória política em democracias com herança autoritária. Tese (Doutorado em Filosofia) - Faculdade de Filosofia, Letras e Ciências Humanas, USP, São Paulo, 2007.

TELES, Janaína. As disputas pela interpretação da Lei de Anistia de 1979. Revista Ideias, Campinas (SP), n. 1, p. 71-93, 2010.

TRINDADE, Tatiana. O papel materno na resistência à ditadura: o caso das mães de Flávio Tavares, Flávio Koutzii e Flávia Schilling. Monografia de conclusão de curso. Departamento de História. Porto Alegre: UFRGS, 2009.

YACCAR, María Daniela. Al piano, en la Casa Rosada. Página/12, 14 Dez. 2014. Disponível em: http://www.pagina12.com.ar/diario/elpais/1-261946-2014-12-14.html (Verificado em 25/01/2015).

ZAVERUCHA, Jorge. Justiça de transição. Folha de São Paulo, São Paulo, 13. Jan. 2010. http://www1.folha.uol.com.br/fsp/opiniao/fz1301201008.htm?mobile (Verificado em 24/01/2015).

\section{GANPHLAC}

Revista Eletrônica da ANPHLAC, ISSN 1679-1061, №. 18, p. 251-286, jan./jul. 2015. 